\title{
COVID-19 vaccines - are we there yet?
}

\section{SUMMARY}

The novel coronavirus SARS-CoV-2, the cause of the COVID-19 pandemic, is a highly infectious human respiratory pathogen to which the global population had no prior immunity. The virus will likely continue to cause significant morbidity until there is a broadly effective vaccine.

As of mid-December 2020, more than 200 COVID-19 vaccine candidates are in development and 11 have entered phase III clinical trials globally. All generate immunity to the viral spike glycoprotein.

Three vaccine candidates have agreements for procurement and use in Australia if efficacy and safety requirements are met - one protein-based vaccine, one vaccine using a simian-derived adenovirus vector and one messenger RNA vaccine. The latter two vaccines have published interim analyses and efficacy results of their phase III trials. The messenger RNA vaccine is being rolled out in the UK, USA and Canada.

Significant uncertainties remain. How well will some of those at highest risk of severe disease (such as older people aged $>75$ years and those with immunocompromising conditions) be protected by a vaccine, and for how long? Also, to what extent will vaccination protect against infection? This will determine the degree of indirect 'herd' protection needed through broad vaccine coverage of younger age groups.

\section{Introduction}

Like influenza, coronaviruses are RNA viruses. The SARS-CoV-2 virus which causes COVID-19 belongs to the betacoronavirus family. This also includes the SARS-CoV-1 virus which causes Severe Acute Respiratory Syndrome (SARS) and MERS-CoV which causes Middle East Respiratory Syndrome (MERS). Another four seasonal human coronaviruses circulate annually, mostly causing mild upper respiratory tract infections.

SARS (2003) and MERS (2014) caused short-lived epidemics with a high case fatality. MERS still occurs sporadically, but SARS-CoV-1 has not been in circulation since 2008 .

COVID-19 is most severe in the elderly and those with significant comorbidities. SARS-CoV-2 also results in asymptomatic infection. Unlike SARS-CoV-1, SARS-CoV-2 can be very contagious before and shortly after symptom onset, which has helped drive rapid global spread. Although estimates of the degree of immunity in the population required to control the COVID-19 pandemic vary, most centre around $60-70 \%{ }^{2}$ High coverage with effective vaccines is the only ethically acceptable path to achieving this level of immunity. The effectiveness of the various COVID-19 vaccine candidates will depend on their ability to reduce infectiousness versus their ability to prevent serious disease if someone gets infected.

\section{Pandemic preparedness}

Experience of disease outbreaks over the past two decades, including SARS and MERS, influenza in 2009, Ebola 3 in 2014 and the emergence of Zika virus, has underpinned rapid progress towards vaccines for COVID-19. This has been enabled by remarkable innovations in fundamental vaccine research and development. ${ }^{4}$ Establishing the Coalition for Epidemic Preparedness and Innovations in 2017 was very timely and has helped to identify and give financial support to candidate vaccines against diseases with pandemic potential, including MERS.

\section{Vaccine development}

Vaccination is only successful if vaccine development results in a product approved for use and delivered to the target population. The vaccine development process is stepwise, pyramidal and selective..$^{5}$ If initial studies in the laboratory (in cell lines and experimental animals) are favourable, human vaccine trials enter the phase I stage which assesses safety, dosage and immunogenicity in small numbers of healthy people. Typically, only a small proportion of vaccine candidates progress to phase II trials, which are designed to identify optimal formulations, numbers of doses and dosing intervals. These trials require hundreds to around a thousand participants. Phase III vaccine trials evaluate protective efficacy against clinical disease as well as safety. Their study size depends on the expected number of cases but is usually many thousands.
Peter McIntyre

Senior professorial fellow? Professor ${ }^{2}$

Professor $r^{3}$

\section{Ye Jin Joo (D)}

Research officer'

Research affiliate ${ }^{2}$

\section{Clayton Chiu}

Associate director and Public health physician Lecturer $^{2}$

\section{Katie Flanagan (D)}

Head of Infectious Diseases ${ }^{4}$

Clinical professor ${ }^{5}$

Adjunct professor ${ }^{6}$

Adjunct associate professor

\section{Kristine Macartney}

Director ${ }^{1}$

Professor ${ }^{2}$

Infectious disease paediatrician $^{8}$

\section{' National Centre for}

Immunisation Research and Surveillance (NCIRS)

${ }^{2}$ Faculty of Medicine and Health, University of Sydney

${ }^{3}$ Women's and Children's Health, University of Otago

${ }^{4}$ Department of Infectious

Diseases, Launceston

General Hospital

${ }^{5}$ Department of Medicine,

University of Tasmania

${ }^{6}$ School of Health and Biomedical Science, RMIT Melbourne

${ }^{7}$ Department of

Immunology and Pathology, Monash University

${ }^{8}$ Department of Microbiology and Infectious Diseases

Children's Hospital Westmead

\section{Keywords}

clinical trials, coronavirus, COVID-19, immunisation, vaccine safety

Aust Prescr 2021;44:19-25

https://doi.org/10.18773/ austprescr.2020.084

First published

17 December 2020 
Progress through all trial stages usually takes at least 10 years. However, the magnitude of the COVID-19 pandemic has led to funding for the development of 'vaccines at pandemic speed' by running some processes in parallel (see Fig. 1). ${ }^{4}$ Many studies have combined phase I and II trials and a few have combined phase II and III trials to compress time frames. This has not compromised scientific rigour as safety, immunogenicity and efficacy outcomes are strictly assessed and safety monitoring will continue even after registration.

As of mid-December 2020, four COVID-19 vaccines have reported estimates of efficacy from their phase III trials in press releases. ${ }^{6}$ However, only two of these, one adenovirus-vectored vaccine (University of Oxford/AstraZeneca) and one messenger RNA vaccine (BioNTech/Pfizer), have published interim efficacy results. ${ }^{7,8}$ Although vaccines produced in China and Russia have been approved for use in those countries (Table 1), detailed efficacy and safety data at the level required by regulatory bodies in most countries, including Australia, are not currently publicly accessible. COVID-19 vaccine candidates have been developed using conventional and novel approaches to vaccine development (see Fig. 2). All of them generate immunity to the viral spike glycoprotein, which is required for the virus to enter host cells. The aim of vaccine-generated antibodies against the spike glycoprotein is to prevent viral replication, or 'neutralise' the virus, and stop it from infecting cells.

\section{Conventional approaches}

Conventional approaches to vaccine development have the advantage of being familiar and well-studied, but these vaccines may take longer to manufacture. COVID-19 vaccine candidates developed by conventional approaches and currently in clinical trials include:

- inactivated viral vaccines (like the influenza (split virus) and inactivated polio (whole virus) vaccines)

- $\quad$ protein or protein subunit vaccines (like the diphtheria and tetanus protein (toxoid) vaccines, hepatitis B and herpes zoster adjuvanted vaccine)

- virus-like particles (like the human papillomavirus vaccine)

- live-attenuated viral vaccines

Only one live-attenuated COVID-19 vaccine is currently being progressed to human studies (NCT04619628).

\section{Novel vaccine approaches}

Novel approaches have potential advantages in the strength of immune responses and rapidity of manufacture but are less well studied. These newer technologies for COVID-19 include viral vectored vaccines and mRNA and DNA vaccines. Vectored vaccines currently in phase III trial use adenoviruses of human or non-human primate origin. These are harmless, non-replicating viruses which are able to enter cells and deliver the genetic code for SARSCoV-2 spike protein antigen. DNA-based vaccines may require specific devices to deliver the DNA into cells (e.g. by electroporation), and from the cytoplasm to the nucleus once in the cell. Conversely, mRNA vaccines are often encapsulated into lipid nanoparticles which allow mRNA to fuse into the cytoplasm without being degraded (Moderna and BioNTech/Pfizer's vaccines use this technology). Both DNA and mRNA vaccines induce the recipient's own cells to produce SARS-CoV-2 spike protein.

\section{COVID-19 vaccines in clinical trials}

Table 1 lists the characteristics of the 11 vaccine candidates in phase III trials as of mid-December 2020.7-17 Table 2 lists vaccines in phase I or II trials in Australia.

Australia currently has one agreement to locally manufacture a vaccine - ChAdOx1 nCoV-19/AZD1222 (University of Oxford/AstraZeneca). This is a viral vectored vaccine in phase III trials, with interim efficacy results. ${ }^{7}$ Previously the University of Queensland/CSL had an agreement for local manufacture of the v451 clamp vaccine. However a decision has been made to not proceed into phase III clinical trials as antibodies to the vaccine interfere with HIV screening tests. ${ }^{18,19}$

\section{Vaccine registration}

All COVID-19 vaccines used in Australia will require approval by the Therapeutic Goods Administration (TGA). The TGA has recently determined that three vaccines in phase III trials are eligible to apply for provisional registration in the Australian Register of Therapeutic Goods. These are:

- BNT162b2 (mRNA vaccine)

- ChAdOx1 nCoV-19/AZD1222 (viral vectored vaccine)

- $\quad$ Ad26.CoV2.S (viral vectored vaccine).

Provisional TGA registration of medicines or vaccines is on the basis of preliminary clinical data on quality, safety and effectiveness of the vaccine, and the sponsor's plan to submit comprehensive clinical and stability data before the provisional registration ends. ${ }^{20}$

The status of other vaccine candidates is available through the World Health Organization website which is regularly updated. ${ }^{21}$ As of mid-December, the BNT162b2 vaccine has been granted Emergency Use Authorisation in at least three countries, including the UK, Canada and the USA, where it is being rolled out in COVID-19 vaccination programs. 


\section{Fig. 1 Timeline of COVID-19 vaccine development and approval compared to conventional vaccine pathway}

Conventional pathway of vaccine development

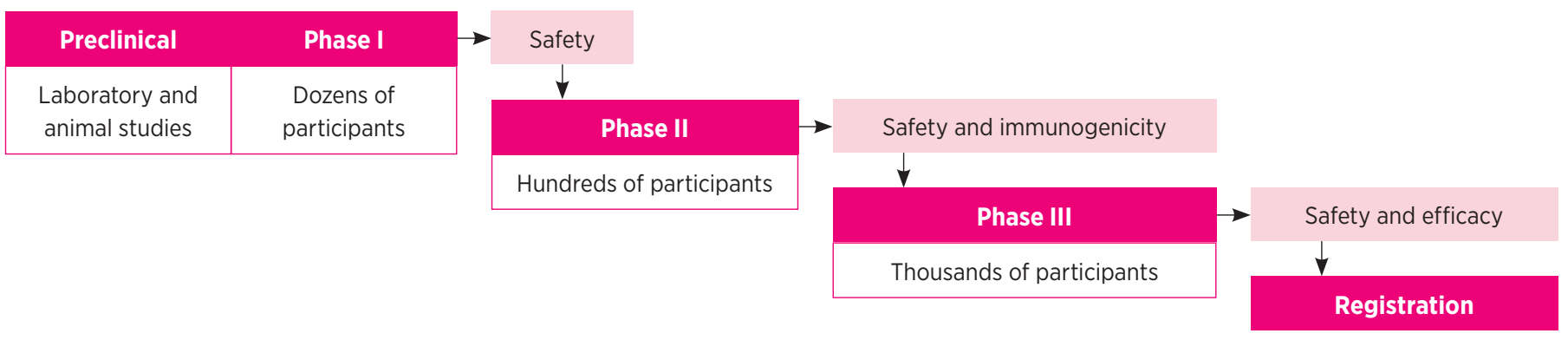

COVID-19 vaccine development at pandemic speed

\section{Preclinical}

Laboratory and animal studies

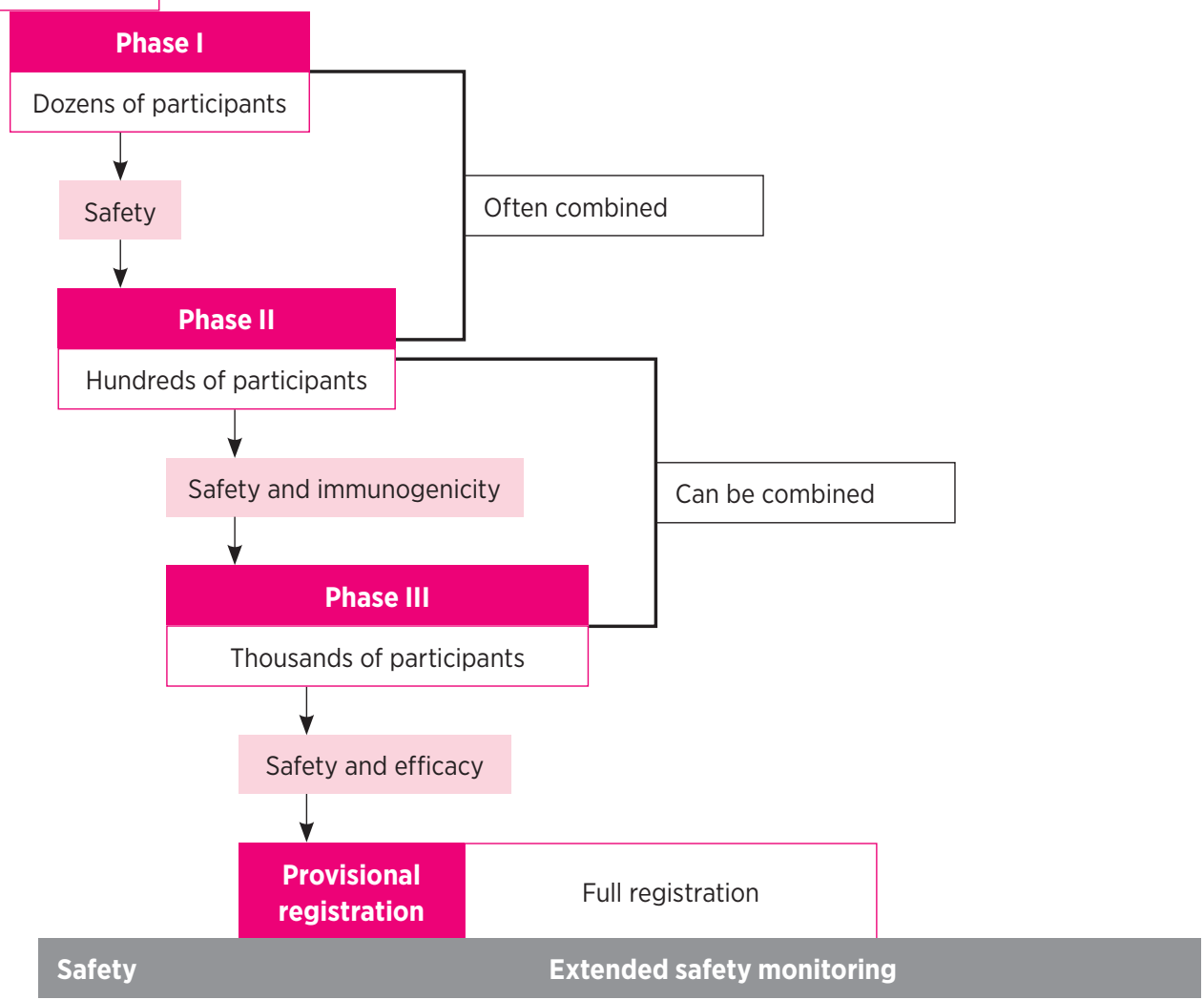


Table 1 COVID-19 vaccine candidates in phase III clinical trials worldwide (as of mid-December 2020)

\begin{tabular}{|c|c|c|c|c|c|}
\hline Vaccine & Developer (country) & Platform technology & $\begin{array}{l}\text { Dose } \\
\text { schedule }\end{array}$ & Published results & $\begin{array}{l}\text { Published Phase III } \\
\text { efficacy }\end{array}$ \\
\hline $\begin{array}{l}\text { ChAdOx1 nCoV-19/ } \\
\text { AZD1222* }\end{array}$ & $\begin{array}{l}\text { University of Oxford/ } \\
\text { AstraZeneca (UK) }\end{array}$ & $\begin{array}{l}\text { Viral vector (chimpanzee } \\
\text { adenovirus vector) }\end{array}$ & 2 doses & $\begin{array}{l}\text { Phase } \mathrm{I} / \|^{9} \\
\text { Phase } I / / I^{10} \\
\text { Phase } \mathrm{I} / \mathrm{II} \text { and } \| \mathrm{II}^{7}\end{array}$ & $\begin{array}{l}\text { Half dose and then } \\
\text { full dose: } \\
90 \% \\
\text { (95\% Cl: } 67.4-97 \%) \\
\text { Two full doses: } \\
62.1 \% \\
(95 \% \text { Cl: } 41-75.7 \%)^{7}\end{array}$ \\
\hline mRNA-1273 & $\begin{array}{l}\text { Moderna/NIAID } \\
\text { (USA) }\end{array}$ & mRNA (lipid nanoparticle) & 2 doses & $\begin{array}{l}\text { Phase I } \\
(18-55 \text { years })^{11} \\
\text { Phase I } \\
(\geq 56 \text { years })^{12}\end{array}$ & \\
\hline CoronaVac & $\begin{array}{l}\text { Sinovac Biotech } \\
\text { (China) }\end{array}$ & Inactivated virus & 2 doses & & \\
\hline Unnamed & $\begin{array}{l}\text { Beijing Institute of Biological } \\
\text { Products/Sinopharm (China) }\end{array}$ & Inactivated virus & 2 doses & & \\
\hline Unnamed & $\begin{array}{l}\text { Wuhan Institute of Biological } \\
\text { Products/Sinopharm (China) }\end{array}$ & Inactivated virus & 2 doses & & \\
\hline BNT162b2* & $\begin{array}{l}\text { BioNTech/Pfizer } \\
\text { (Germany, USA) }\end{array}$ & mRNA (lipid nanoparticle) & 2 doses & $\begin{array}{l}\text { Phase I/II' } \\
\text { Phase II/III }\end{array}$ & $\begin{array}{l}\text { Two doses: } \\
\text { 95\% } \\
(95 \% \mathrm{Cl}: 90.3-97.6 \%)^{8}\end{array}$ \\
\hline Gam-COVID-Vac & $\begin{array}{l}\text { Gamaleya Research Institute } \\
\text { (Russia) }\end{array}$ & $\begin{array}{l}\text { Viral vector (human } \\
\text { adenovirus type } 26 \text { and } 5 \text {, } \\
\text { sequentially administered) }\end{array}$ & $\begin{array}{l}2 \text { doses in } \\
\text { total }\end{array}$ & Phase $\mathrm{I} / \mathrm{II}^{14}$ & \\
\hline Ad5-nCoV & $\begin{array}{l}\text { CanSino Biologics } \\
\text { (China) }\end{array}$ & $\begin{array}{l}\text { Viral vector (human } \\
\text { adenovirus type 5) }\end{array}$ & 2 doses & $\begin{array}{l}\text { Phase } I^{15} \\
\text { Phase } I^{16}\end{array}$ & \\
\hline NVX-CoV2373* & $\begin{array}{l}\text { Novavax } \\
\text { (USA) }\end{array}$ & $\begin{array}{l}\text { Protein lipid nanoparticle } \\
\text { with Matrix M adjuvant }\end{array}$ & 2 doses & Phase $1^{17}$ & \\
\hline Ad26.CoV2.S & $\begin{array}{l}\text { Janssen/Johnson \& Johnson } \\
\text { (USA) }\end{array}$ & $\begin{array}{l}\text { Viral vector (human } \\
\text { adenovirus type } 26 \text { ) }\end{array}$ & 1 dose & & \\
\hline $\begin{array}{l}\text { BBV152B/ } \\
\text { Covaxin }\end{array}$ & $\begin{array}{l}\text { Bharat Biotech International } \\
\text { (India) }\end{array}$ & Inactivated virus & 2 doses & & \\
\hline
\end{tabular}

* Australian Government has advance purchase agreements for ChAdOx1 nCoV-19/AZD1222, BNT162b2 and NVX-CoV2373 subject to registration requirements

\section{Vaccine safety}

Safety is paramount at all stages of the clinical development process. It is built into vaccine development by guidelines from the earliest stages (Good Laboratory Practice) to clinical trials (Good Clinical Practice). For each vaccine, safety is assessed by Data Safety Monitoring Boards, independent of the manufacturer, during the trial. Safety is also assessed after trial completion by the regulator when it reviews the vaccine for approval. ${ }^{22}$

In Australia, enhanced reporting of adverse events following immunisation (AEFI) at national and state and territory levels is designed to ensure that the safety of any COVID-19 vaccines used in the
National Immunisation Program is comprehensively monitored. This is supplemented by near real-time active vaccine safety surveillance, such as through AusVaxSafety. ${ }^{23}$ All these mechanisms will be outlined in detail in the Australian national COVID-19 vaccine pharmacovigilance plan.

Some potential safety concerns were identified early on for COVID-19 vaccine candidates based on previous experience with coronavirus vaccine candidates. In experimental animals given vaccines for SARS and MERS, some studies showed evidence of lung immunopathology after challenge with wild virus (termed disease enhancement). ${ }^{24}$ However, this proved not to be an issue for COVID-19 
vaccines in animal studies, as high concentrations of neutralising antibody were produced. These antibodies not only bind to viral antigen, they also prevent the virus from infecting cells. In addition, the T-cell responses seen were not associated with allergy (i.e. $T$ helper 1 biased rather than $T$ helper 2). ${ }^{24}$ It is a requirement that vaccine candidates satisfy these criteria before entering phase I human trials. To date, no COVID-19 candidate vaccines have generated safety signals of concern.

\section{How will we use COVID-19 vaccines?}

There is general agreement that front-line workers, such as healthcare staff, and individuals at the highest risk of severe disease, particularly the elderly, should be prioritised to receive COVID-19 vaccines once available. ${ }^{25-27} \mathrm{~A}$ key question is how well vaccines that show protection in young, healthy individuals will work in people who have chronic medical conditions or are immunocompromised, and in older people, particularly those who are frail or living in residential care. Up until 2020 , the only vaccine with high levels of protection in older people (>70 years) is a recombinant shingles vaccine which uses a novel adjuvant. ${ }^{28}$ This vaccine is available in the USA, but not Australia. Such novel adjuvants may prove important for COVID-19 vaccines in older people and other groups likely to have reduced vaccine responses.

\section{Fig. 2 Approaches being used to develop SARS-CoV-2 vaccines to protect against COVID-19}

CONVENTIONAL APPROACHES
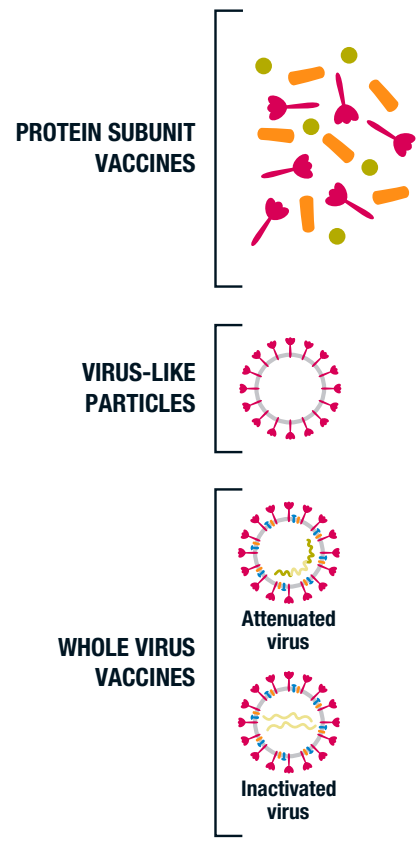

NOVEL APPROACHES

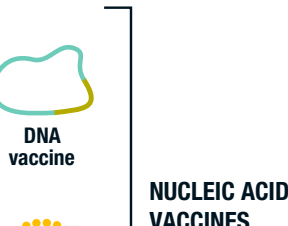

SARS-CoV-2

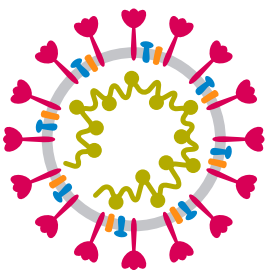
VACCINES

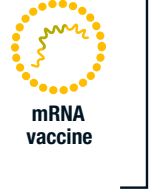

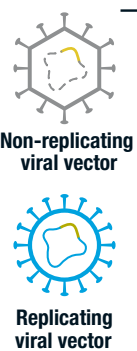

VIRAL VECTOR VACCINES

\section{Table 2 COVID-19 vaccines in human clinical trials in Australia (as of mid-December 2020)}

\begin{tabular}{|c|c|c|c|c|c|c|}
\hline Vaccine & $\begin{array}{l}\text { Developer } \\
\text { (country) }\end{array}$ & $\begin{array}{l}\text { Platform } \\
\text { technology }\end{array}$ & Phase & Clinical trial location & $\begin{array}{l}\text { Age of } \\
\text { participants }\end{array}$ & $\begin{array}{l}\text { Clinical trial } \\
\text { registration }\end{array}$ \\
\hline SCB-2019 & $\begin{array}{l}\text { Clover } \\
\text { Biopharmaceuticals } \\
\text { (China) }\end{array}$ & Protein & 1 & Perth & $18-75$ years & NCT04405908 \\
\hline NVX-CoV2373 & Novavax (USA) & $\begin{array}{l}\text { Protein lipid } \\
\text { nanoparticle } \\
\text { with Matrix M } \\
\text { adjuvant }\end{array}$ & $\mathrm{I} / \mathrm{II}$ & $\begin{array}{l}\text { Melbourne and Brisbane } \\
\text { (phase I) } \\
10 \text { locations in ACT, } \\
\text { NSW, QLD and VIC and } \\
8 \text { in the USA (phase II) }\end{array}$ & $18-59$ years & NCT04368988 \\
\hline Covax-19 & Vaxine (Australia) & Protein & I & Adelaide & 18-84 years & NCT04453852 \\
\hline v451* & $\begin{array}{l}\text { University of } \\
\text { Queensland } \\
\text { (Australia) }\end{array}$ & Protein & I & Brisbane & $18-65$ years & NCT04495933 \\
\hline $\begin{array}{l}\text { RBD-SARS-CoV-2 } \\
\text { HBsAg VLP }\end{array}$ & SpyBiotech (UK) & $\begin{array}{l}\text { Virus-like } \\
\text { particle }\end{array}$ & $1 / I 1$ & Melbourne & $18-79$ years & ACTRN12620000817943 \\
\hline bacTRL-Spike & Symvivo (Canada) & $\begin{array}{l}\text { DNA } \\
\text { (oral } \\
\text { administration) }\end{array}$ & I & Melbourne & $\geq 18$ years & NCT0 4334980 \\
\hline
\end{tabular}

\footnotetext{
* The Australian Government had an advance purchase agreement for v451 vaccine subject to registration requirements. However, further trials of this candidate vaccine have been cancelled due to the vaccine causing false positive HIV tests in those who receive it.18,19 (This is related to a protein fragment contained in the vaccine formulation.)
} 
Another key uncertainty is whether COVID-19 vaccination will reduce transmission of SARS-CoV-2 and produce indirect 'herd' immunity which could protect people who are unable to respond to vaccines. It will take time for data to emerge on this and on the duration of protection and need for repeated doses. ${ }^{29}$

More detailed priorities for specific target groups will vary with the availability of vaccines and their specific characteristics. Vaccine recommendations, along with other control recommendations are evolving as our experience with COVID-19 grows.

\section{Conclusion}

Ensuring public confidence in both the safety and effectiveness of COVID-19 vaccines will be critical to achieving high vaccine uptake among target populations during vaccine roll out in Australia from
2021. 30 As COVID-19 vaccines become available for use, immunisation service providers can take early steps to prepare for vaccine introduction, such as ensuring connectivity to the Australian Immunisation Register and engagement with other systems such as adverse events following immunisation reporting.

Much needs to be done to ensure that the unprecedented scientific effort which has allowed rapid development of COVID-19 vaccines translates into the high vaccine uptake needed to rapidly overcome the most significant global pandemic seen in over a century. $<$

Acknowledgement: We thank Claudio Rosa (www.claudiorosa.com) for medical illustration of Fig. 2

Katie Flanagan is a previous advisory board member for Seqiris and Sanofi Pasteur (in the last five years) and a member of the Australian Technical Advisory Group on Immunisation.

\section{REFERENCES}

1. Petersen E, Koopmans M, Go U, Hamer DH, Petrosillo N, Castelli F, et al. Comparing SARS-CoV-2 with SARS-CoV and influenza pandemics. Lancet Infect Dis 2020;20:e238-44. https://doi.org/10.1016/S1473-3099(20)30484-9

2. Aschwanden $\mathrm{C}$. The false promise of herd immunity. Nature 2020;587:26-8. https://doi.org/10.1038/d41586-020-02948-4

3. Feldmann H, Sprecher A, Geisbert TW. Ebola. N Engl J Med 2020;382:1832-42. https://doi.org/10.1056/NEJMra1901594

4. Lurie N, Saville M, Hatchett R, Halton J. Developing Covid-19 vaccines at pandemic speed. N Engl J Med 2020:382:1969-73. https://doi.org/10.1056/NEJMp2005630

5. Peter $G$, des Vignes-Kendrick M, Eickhoff TC, Fine A, Galvin V, Levine MM, et al.; National Vaccine Advisory Committee. Lessons learned from a review of the development of selected vaccines. Pediatr 1999;104:942-50. https://doi.org/10.1542/peds.104.4.942

6. New York Times COVID vaccine tracker. https://www.nytimes.com/interactive/2020/science/ coronavirus-vaccine-tracker.html [cited 2020 Dec 15]

7. Voysey M, Clemens SA, Madhi SA, Weckx LY, Folegatti PM, Aley PK, et al.; Oxford COVID Vaccine Trial Group. Safety and efficacy of the ChAdOx1 nCoV-19 vaccine (AZD1222) against SARS-CoV-2: an interim analysis of four randomised controlled trials in Brazil, South Africa, and the UK. Lancet 2020 Dec 8. https://doi.org/10.1016/S0140-6736(20)32661-1

8. Polack FP, Thomas SJ, Kitchin N, Absalon J, Gurtman A, Lockhart S, et al: C4591001 Clinical Trial Group. Safety and efficacy of the BNT162b2 mRNA Covid-19 vaccine. N Engl J Med 2020 Dec 10. https://doi.org/10.1056/NEJMoa2034577

9. Folegatti PM, Ewer KJ, Aley PK, Angus B, Becker S, Belij-Rammerstorfer S, et al.; Oxford COVID Vaccine Trial Group. Safety and immunogenicity of the ChAdOx1 nCoV-19 vaccine against SARS-CoV2: a preliminary report of a phase $1 / 2$, singleblind, randomised controlled trial. Lancet 2020; 396:467-78. https://doi.org/10.1016/S0140-6736(20)31604-4

10. Ramasamy MN, Minassian AM, Ewer KJ. Safety and immunogenicity of ChAdOx1 nCoV-19 vaccine administered in a prime-boost regimen in young and old adults (COVO02): a single-blind, randomised, controlled, phase 2/3 trial. Lancet 2020 Nov 18;S0140-6736:32466-1. https://doi.org/ 10.1016/S0140-6736(20)32466-1

11. Jackson LA, Anderson EJ, Rouphael NG, Roberts PC Makhene M, Coler RN, et al.; mRNA-1273 Study Group. An mRNA Vaccine against SARS-CoV-2 - Preliminary Report. N Engl J Med 2020;383:1920-31. https://doi.org/10.1056/ NEJMoa2022483
12. Anderson EJ, Rouphael NG, Widge AT, Jackson LA, Roberts PC, Makhene M, et al.; mRNA-1273 Study Group. Safety and immunogenicity of SARS-CoV-2 mRNA-1273 vaccine in older adults. N Engl J Med 2020 Sep 29. https://doi.org/10.1056/NEJMoa2028436

13. Walsh EE, Frenck RW Jr, Falsey AR, Kitchin N, Absalon J, Gurtman A, et al. Safety and immunogenicity of two RNA-based Covid-19 vaccine candidates. N Engl J Med 2020 Oct 14. https://doi.org/10.1056/NEJMoa2027906

14. Logunov DY, Dolzhikova IV, Zubkova OV, Tukhvatullin Al, Shcheblyakov DV, Dzharullaeva AS, et al. Safety and immunogenicity of an rAd26 and rAd5 vector-based heterologous prime-boost COVID-19 vaccine in two formulations: two open, non-randomised phase 1/2 studies from Russia. Lancet 2020;396:887-97. https://doi.org/ 10.1016/S0140-6736(20)31866-3

15. Zhu FC, Guan XH, Li YH, Huang JY, Jiang T, Hou LH, et al. Immunogenicity and safety of a recombinant adenovirus type-5-vectored COVID-19 vaccine in healthy adults aged 18 years or older: a randomised, double-blind, placebocontrolled, phase 2 trial. Lancet 2020;396:479-88. https://doi.org/10.1016/S0140-6736(20)31605-6

16. Zhu FC, Li YH, Guan XH, Hou LH, Wang WJ, Li JX, et al. Safety, tolerability, and immunogenicity of a recombinant adenovirus type- 5 vectored COVID-19 vaccine: a doseescalation, open-label, non-randomised, first-in-human trial. Lancet 2020;395:1845-54. https://doi.org/10.1016/ S0140-6736(20)31208-3

17. Keech C, Albert G, Cho I, Robertson A, Reed P, Neal S, et al. Phase 1-2 Trial of a SARS-CoV-2 recombinant spike protein nanoparticle vaccine. N Engl J Med 2020;383:2320-32. https://doi.org/10.1056/NEJMoa2026920

18. Ministers Department of Health. Australia secures 20 million extra Astra Zeneca vaccines [Media Release]. 2020 Dec 11 https://www.health.gov.au/ministers/the-hon-greg-hunt$\mathrm{mp} /$ media/australia-secures-20-million-extra-astra-zenecavaccines [cited 2020 Dec 15]

19. University of Queensland. UQ News. Update on UQ COVID-19 vaccine. 2020 Dec 11. https://www.uq.edu.au/news/article/ 2020/12/update-uq-covid-19-vaccine [cited 2020 Dec 15]

20. Australian Government Department of Health. Therapeutic Goods Administration. COVID-19 vaccine approval process. 2020 Nov 27. https://www.tga.gov.au/covid-19-vaccineapproval-process [cited 2020 Dec 15]

21. World Health Organization. Draft landscape of COVID-19 candidate vaccines. 2020 Dec 8. https://www.who.int/ publications/m/item/draft-landscape-of-covid-19-candidatevaccines [cited 2020 Dec 15] 
22. Australian Government Department of Health. Vaccine safety. In: Fundamentals of immunisation. Australian Immunisation Handbook https://immunisationhandbook.health.gov.au/ fundamentals-of-immunisation [cited 2020 Dec 15]

23. Pillsbury A, Cashman P, Leeb A, Regan A, Westphal D, Snelling T, et al.; AusVaxSafety surveillance team. Real-time safety surveillance of seasonal influenza vaccines in children, Australia, 2015. Euro Surveill 2015;20. https://doi.org/10.2807/ 1560-7917.ES.2015.20.43.30050

24. Lambert PH, Ambrosino DM, Andersen SR, Baric RS, Black SB, Chen RT, et al. Consensus summary report for CEPI/BC March 12-13, 2020 meeting: Assessment of risk of disease enhancement with COVID-19 vaccines. Vaccine

2020;38:4783-91. https://doi.org/10.1016/j.vaccine.2020.05.064

25. Persad G, Peek ME, Emanuel EJ. Fairly prioritizing groups for access to COVID-19 vaccines. JAMA 2020 Sep 10. https://doi.org/10.1001/jama.2020.18513

26. World Health Organization. WHO SAGE values framework for the allocation and prioritization of COVID-19 vaccination, 14 September 2020. https://apps.who.int/iris/ handle/10665/334299 [cited 2020 Dec 15]
27. The National Academies of Sciences Engineering Medicine A framework for equitable allocation of vaccine for the novel coronavirus. https://www.nationalacademies.org/ourwork/a-framework-for-equitable-allocation-of-vaccine-forthe-novel-coronavirus [cited 2020 Dec 15]

28. Cunningham AL, Lal H, Kovac M, Chlibek R, Hwang SJ, Díez-Domingo J, et al.; ZOE-70 Study Group. Efficacy of the herpes zoster subunit vaccine in adults 70 years of age or older. N Engl J Med 2016;375:1019-32. https://doi.org/ 10.1056/NEJMoa1603800

29. Flanagan KL, Best E, Crawford NW, Giles M, Koirala A, Macartney $\mathrm{K}$, et al. Progress and pitfalls in the quest for effective SARS-CoV-2 (COVID-19) vaccines frontiers in immunology. Front Immunol 2020;11:579250. https://doi.org/10.3389/fimmu.2020.579250

30. Danchin M, Biezen R, Manski-Nankervis JM, Kaugman J, Leask J. Preparing the public for COVID-19 vaccines: how can general practitioners build vaccine confidence and optimise uptake for themselves and their patients? AJGP 2020:49:625-9. https://doi.org/10.31128/AJGP-08-20-5559

\section{FURTHER READING}

Brischetto, Robson J. Testing for COVID-19. Aust Prescr

2020 Oct 15. https://doi.org/10.18773/austprescr.2020.067 